\title{
Characteristics of Traffic Flows at Kuda Mati non-traffic light Intersection in Workhour and Holidays
}

\author{
Herbin F. Betaubun ${ }^{1 *}$ \\ ${ }^{1}$ Faculty of Engineering, Musamus University, Merauke-Indonesia
}

\begin{abstract}
Characteristics of traffic flow needs to be revealed to describe the traffic flow that occurred at the research location. One of the patterns of traffic flow movement of Merauke Regency that is important enough to be observed is the movement pattern that occurs at Kuda Mati Non-traffic lights Intersection. This intersection is one of the access for economic support of Merauke Regency. The intersection connects the city center to the production centers and is used by the community to perform activities in meeting their needs such as working and meeting the needs of clothing, food and shelter. This fulfillment activity is usually differentiated according to work time and holiday time. The method used is survey method to describe the characteristics of traffic flow at the intersection. Data analysis applied MKJI 1997. The results show that peak hour traffic flow occurs at $17.00-18.00$ on holiday $803 \mathrm{smp} /$ hour, while for working time the traffic flow is evenly distributed with maximum vehicle volume occur at 12:00 to 13:00 which amounted to $471 \mathrm{smp} /$ hour.
\end{abstract}

Keywords: Characteristic of traffic flow; Simpang Four Tak Bersinyal; Working time ; Holiday.

\section{Introduction}

Merauke Regency is one of the districts located in the province of Papua and is located between $137^{\circ}-141^{\circ}$ East Longitude and $5^{\circ}-9^{\circ}$ South Latitude. Merauke Regency is also the largest regency in Papua province with wide reaching up to $46,791,63 \mathrm{~km}^{2}$ or 14,67 percent from entire territory of Papua Province [1]. In addition, Merauke Regency is also included in one of the development targets in terms of agriculture. Rice is one of the main agricultural products of the area. Transportation is important for the distribution of rice from production centers to downtown.

Transportation is an activity of moving passengers and goods from one place to another. Elements of movement in physical transportation is the changing of places of goods or passengers either using tools or without means of transport to other places.

Transportation system is done to coordinate the process of movement of passengers and goods by arrangement of its components where the infrastructure is a very important media for transportation process. In this case, the infrastructure in question is a highway (land infrastructure). The highway is an infrastructure or a place to pass either vehicle or motor vehicle in which three components of the occurrence of human traffic: users, vehicles, and roads interact with each other.

Transport planning is needed as a consequence of the growth of traffic conditions and area expansion.
Transportation planning is a systematic transportation system planning activity that aims to provide transportation services, both facilities and infrastructure tailored to the needs of people in the area. Transport planning studies the factors that affect people's needs for the movement of people or goods. These factors are usually land use, economic, socio-cultural, transportation technology and many other factors that can be related to the needs of the community.

The pattern of transportation movement that continues to grow becomes a problem that must be solved for the improvement of the economy. The pattern of movement that can be reviewed, among others, is the intersection which which serves as the meeting point of several roads. Intersection is a meeting of two or more streets. At the intersection, there is always a conflict between two or more traffic flows on the interlocking streets.

Characteristic of traffic flow needs to be done to describe the traffic flow that occurred at the research location. The traffic (volume) current expressed by the $\mathrm{V}$ notation is the number of vehicles passing through a certain point in a particular road in a given time unit, usually expressed in units of vehicles / hour. [2]

One of the patterns of traffic flow movement of Merauke Regency which is important to be observed is the pattern of movement that occurs at Kuda Mati Intersection. Based on the type of the intersection, it is considered as intersection with no trafic light. This

* Corresponding author: herbin@unmus.ac.id 
intersection is also one of the access economic support of Merauke Regency. The intersection is one of the strategic intersections for the economy in Merauke Regency. The intersection connects the city center with production centers such as Semangga District, Kurik District, Tanah Lean District, and Jagebob District. In addition, the intersection is also used for community activities in meeting their daily needs for both work and clothing, food and board needs from the center of activity in Merauke District. One of the factors that affect the rate of movements of a city is land use development. Land use also indirectly influences side barriers in certain road conditions, activities can grow which can cause side barriers that greatly affect the characteristics of the road itself. [3] This fulfillment activity is usually differentiated according to work time and holiday time. The impact can be seen in the level of violation of speed limiting signs at the points surveyed in Merauke District is very high, especially the speed of vehicles $20-25 \mathrm{~km} /$ hour. [4]

Based on the above problems, the researchers conduct a study related to the characteristics of traffic flow that occurred at work and holiday time.

\section{Research Method}

This research was done by survey method. Survey method was a method that was often used in research. Survey method was usually used to provide a general description of the object of research. Survey was conducted to obtain representative data about the amount of traffic flow, in this case is the amount of traffic flow that occurred at the intersection. There were two methods of traffic surveys that are commonly used: manual surveys and mechanical surveys.

The manual implementation method applied surveyor personnel to calculate traffic flow through a piece of road, this survey requires a large labor cost, but can be done easily. Yet, the accuracy of the results depends largely on the expertise of the surveyor in minimizing the error factor. The mechanical execution method was carried out using mechanical or electronic equipment such as pneumatic tubes, induction loops, infrared / ultra sonic waves, video cameras, and other mechanical devices. In this research, the survey implementation method was done manually.

\subsection{Time and Location of Survey}

The following is a general overview of the geometric location of the survey ie the traffic light-less kuda mati intersection.

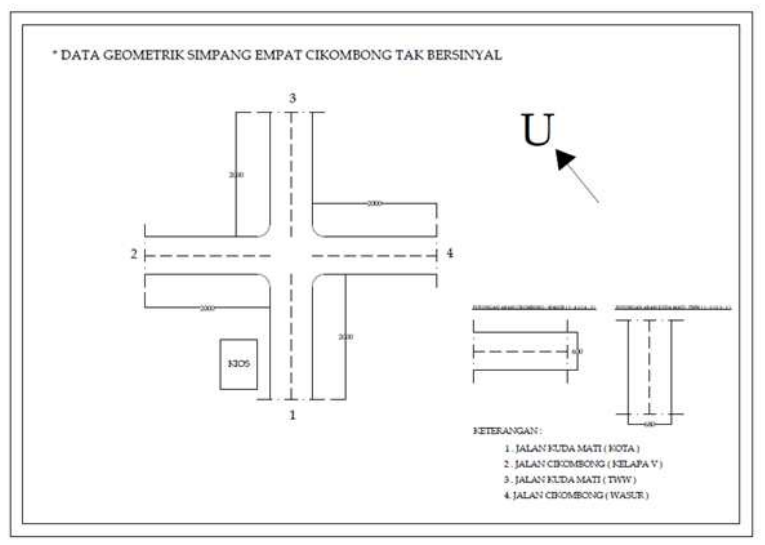

Figure 1. Geometric Data of Kuda Mati Intersection (no traffic light)

The survey was conducted in May 2018. The survey time was determined based on peak hour. Data Taken for three periods ie morning, noon and afternoon ( 2 hours each). The survey time was determined based on peak hour at the intersection. For busy time determination can be done visually for 12 hours.

\subsection{Survey Preparation}

One of the important things that must be prepared before the survey begin was the equipment that will be used such as a roll meter for the measurement of the intersection so that the results obtained can describe the geometric, traffic counters for the enumeration of vehicles through the intersection, stationery and stopwatch as a timer. Then, the survey form should be prepared first.

Human resources (surveyor) was also a determining factor of success and fluency of the survey itself. Surveyors should be directed so that the error factors can be reduced to a minimum. The survey was conducted 30 minutes before the survey was started so that the surveyors could be directed by the head of the survey group.

\subsection{Survey Data Analysis}

Traffic (volume) expressed under one hour (sub hour) such as 15 minutes known as the rate of flow or current value. Motor vehicles were classified into light vehicles, heavy vehicles, and motorbike vehicles by type.

To get the current value of a road segment consisting of many types of vehicles then all types of vehicles must be converted into units of passenger cars (smp). Conversion of vehicles into units of smp required passenger equivalent for each type of vehicle. Based on Indonesian Road Capacity Manual 1997 for non-signal intersection, passenger car equivalent number can be seen in Table 1.[5] 
Table 1. Vehicle equivalent number.

\begin{tabular}{|l|l|}
\hline Type & EMP number \\
\hline Light vehicle & 1 \\
\hline Heavy vehicle & 1,3 \\
\hline Motorcycle & 0,5 \\
\hline
\end{tabular}

\section{Result of the Research}

Here is the result of research in the form of traffic flow at work time and time off at Kuda Mati intersection.

\subsection{Traffic Flow at Kuda Mati Intersection in Wokhours}

The result of traffic flow analysis at Kuda Mati Intersection at workhours (Tuesday) can be seen in Table 2. and Figure 2.

Table 2. Flow of Traffic at Workhours.

\begin{tabular}{|c|c|c|c|c|c|}
\hline \multirow{2}{*}{ Period } & \multirow{2}{*}{ Time } & \multirow{2}{*}{ Arm Intersection } & \multicolumn{2}{|c|}{ Volume } & \multirow{2}{*}{$\begin{array}{l}\text { Volume Max } \\
\text { pcu/hour }\end{array}$} \\
\hline & & & vehicle/hour & pcu/hour & \\
\hline \multirow{8}{*}{ Morning } & \multirow{4}{*}{$06.20-07.20$} & 1 & 564 & 325 & \multirow{4}{*}{325} \\
\hline & & 2 & 19 & 10 & \\
\hline & & 3 & 536 & 305 & \\
\hline & & 4 & 44 & 24 & \\
\hline & \multirow{4}{*}{$07.20-08.20$} & 1 & 642 & 376 & \multirow{4}{*}{376} \\
\hline & & 2 & 16 & 8 & \\
\hline & & 3 & 625 & 365 & \\
\hline & & 4 & 46 & 28 & \\
\hline \multirow{8}{*}{ Afternoon } & \multirow{4}{*}{$11.00-12.00$} & 1 & 758 & 485 & \multirow{4}{*}{485} \\
\hline & & 2 & 13 & 7 & \\
\hline & & 3 & 725 & 459 & \\
\hline & & 4 & 148 & 98 & \\
\hline & \multirow{4}{*}{$12.00-13.00$} & 1 & 819 & 514 & \multirow{4}{*}{514} \\
\hline & & 2 & 14 & 7 & \\
\hline & & 3 & 776 & 492 & \\
\hline & & 4 & 146 & 90 & \\
\hline \multirow{8}{*}{ Evening } & \multirow{4}{*}{$17.00-18.00$} & 1 & 1339 & 803 & \multirow{4}{*}{803} \\
\hline & & 2 & 23 & 12 & \\
\hline & & 3 & 1222 & 730 & \\
\hline & & 4 & 74 & 43 & \\
\hline & \multirow{4}{*}{$18.00-19.00$} & 1 & 979 & 590 & \multirow{4}{*}{590} \\
\hline & & 2 & 20 & 11 & \\
\hline & & 3 & 917 & 552 & \\
\hline & & 4 & 49 & 31 & \\
\hline
\end{tabular}

The above data shows that on the workhours, the first street (Kuda Mati) and the 3rd street (Tujuh WaliWali) are the most commonly used street by light vehicles, heavy vehicles, and motorcycles when compared to the 2 nd street and the 4 th street.

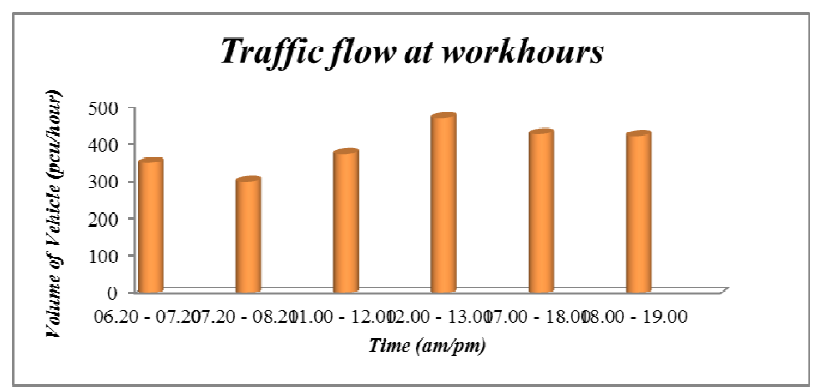

Figure 2. Traffic flow at workhours

From the above result, the peak hour is the traffic flows from 17:00 to 18:00 on holidays of $803 \mathrm{smp} /$ hour.

\subsection{The traffic flow of Kuda Mati intersection in holidays}

The result of traffic flow analysis of Kuda Mati intersection in holidays (sunday) can be seen in Table 3 . and Figure 3.

Table 3. Flow of Traffic At Holiday.

\begin{tabular}{|c|c|c|c|c|c|}
\hline \multirow{2}{*}{ Period } & \multirow{2}{*}{ Time } & \multirow{2}{*}{ Arm Intersection } & \multicolumn{2}{|c|}{ Volume } & \multirow{2}{*}{$\begin{array}{l}\text { Volume Max } \\
\text { pcu/hour }\end{array}$} \\
\hline & & & vehicle/hour & pcu/hour & \\
\hline \multirow{8}{*}{ Morning } & \multirow{4}{*}{$06.20-07.20$} & 1 & 612 & 349 & \multirow{4}{*}{351} \\
\hline & & 2 & 18 & 13 & \\
\hline & & 3 & 610 & 351 & \\
\hline & & 4 & 40 & 23 & \\
\hline & \multirow{4}{*}{$07.20-08.20$} & 1 & 486 & 297 & \multirow{4}{*}{300} \\
\hline & & 2 & 14 & 10 & \\
\hline & & 3 & 487 & 300 & \\
\hline & & 4 & 47 & 34 & \\
\hline \multirow{8}{*}{ Afternoon } & \multirow{4}{*}{$11.00-12.00$} & 1 & 595 & 375 & \multirow{4}{*}{375} \\
\hline & & 2 & 36 & 25 & \\
\hline & & 3 & 563 & 352 & \\
\hline & & 4 & 123 & 93 & \\
\hline & \multirow{4}{*}{$12.00-13.00$} & 1 & 731 & 471 & \multirow{4}{*}{471} \\
\hline & & 2 & 25 & 17 & \\
\hline & & 3 & 699 & 453 & \\
\hline & & 4 & 109 & 78 & \\
\hline \multirow{8}{*}{ Evening } & \multirow{4}{*}{$17.00-18.00$} & 1 & 710 & 428 & \multirow{4}{*}{428} \\
\hline & & 2 & 72 & 45 & \\
\hline & & 3 & 652 & 389 & \\
\hline & & 4 & 30 & 21 & \\
\hline & \multirow{4}{*}{$18.00-19.00$} & 1 & 680 & 424 & \multirow{4}{*}{424} \\
\hline & & 2 & 26 & 16 & \\
\hline & & 3 & 611 & 382 & \\
\hline & & 4 & 18 & 11 & \\
\hline
\end{tabular}

The same condition with the data of workhours also occurs on holiday, from the data above can be seen that on the workhours of the 1st street (Kuda Mati) and the 3rd street (Tujuh Wali-Wali) are the street often used either light vehicle, heavy vehicles, and motorcycles when compared to the 2 nd street and 4 th street.

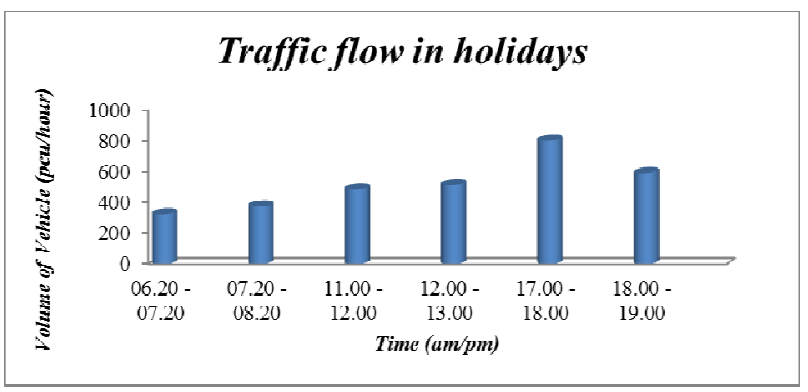

Figure 3. Traffic flow in holidays

At workhours, traffic flow is evenly distributed with maximum vehicle volume occurred at $12.00-13.00$ that is equal to $471 \mathrm{smp}$ / hour.

\section{Conclusion}

Based on the results of the above study it can be seen that the peak hour of traffic flow at the intersection occurred at 17:00 to $18: 00$ in the holiday that is equal to 803 smp / hour, when compared to workhours, the distribution of vehicles divided evenly with maximum volume occurred at $12.00-13.00$ that is equal to 471 smp / hour. 


\section{References}

1. BPS Kabupaten Merauke, Merauke Dalam Angka. BPS Kabupaten Merauke, 2017.

2. O. Tamin, Perencanaan dan Pemodelan Tranportasi, Kedua. Bandung: Penerbit ITB, 1997.

3. Najid and H. F. Betaubun, "Pengaruh Karakteristik Jalan dan Tata Guna Lahan pada Penentuan Kapasitas Jalan Studi Kasus: Jakarta Barat," in FSTPT, 2012, p. 11.
4. H. F. Betaubun and P. Betaubun, "Evaluation of the Performance of Traffic Signs for Vehicle Speed Limits in Merauke District," Int. J. Civ. Eng. Technol. (IJCIET, vol. 9, no. 8, pp. 568-573, 2018.

5. D. G. of H. D. of U. R. Development, Manual Kapasitas Jalan Indonesia, 1997. 